\title{
Criteria for sustainable fisheries on juveniles illustrated for Mediterranean hake: control the juvenile harvest, and safeguard spawning refugia to rebuild population fecundity
}

\author{
John F. Caddy \\ E-mail: jfcaddy1@yahoo.co.uk
}

\begin{abstract}
Summary: The paper provides a broad overview of issues relevant to management of fisheries for juvenile fish in contrast to the many stock assessments following Beverton and Holt's (1957) approach for rational exploitation of mature fishes. A perspective on assessing these fisheries is illustrated for juvenile European hake, Merluccius merluccius, in the northwestern Mediterranean. Here, a constant natural mortality (M) assumption is incorrect, as is the assumption that high fecundities are necessarily adequate for stock replacement. The high Ms-at-age for juveniles generated by the reciprocal model are shown to be a logical counterpart to the high fecundity of hake. Charnov's criterion of intergenerational reproductive replacement is used to test for a sustainable population, analogous to a limit reference point warning of the dangers of overfishing beyond population replacement. Once peak mortality rates of age 2 hake exceed $\mathrm{F}(2)=1.1-1.2$, which is currently the case, reproductive replacement may be at risk. Adult exploitation by inshore trawls is low, and maturing hake surviving the fine-mesh trawl fishery migrate offshore with a reduced vulnerability to fine-mesh gears. Early research suggested that rough bottom near the shelf edge once formed a refugium protecting offshore spawners from trawling, and led to abundant recruitment of juveniles nearer shore. It may not do so if offshore fishing effort by reinforced bottom trawls, gill nets and longlines is uncontrolled. Restoring offshore refugia to protect spawners and controlling peak fishing mortality of juveniles would be a precautionary strategy aimed at restoring previous levels of recruitment to the small-mesh trawl fishery.
\end{abstract}

Keywords: harvesting juveniles; European hake; natural mortality at age; population fecundity; spawning refugia; intergenerational ratio; Charnov's criterion; Mediterranean Sea.

Criterio para una pesca sostenible de juveniles, tomando como ejemplo la merluza del Mediterráneo: control de la pesca de juveniles y preservación de refugios para reproductores, con el fin de rehacer la fecundidad de la población

Resumen: Este artículo presenta varios temas de relevancia para la gestión pesquera de juveniles que contrastan con las evaluaciones de estocs pesqueros basados en la aproximación de Beverton y Holt (1957) para una explotación racional de los peces maduros. En concreto, se presenta un ejemplo para la pesquería de juveniles de merluza europea, Merluccius merluccius, en el Mediterráneo noroccidental. En este caso, es incorrecto asumir la mortalidad natural (M) como constante, como lo es asumir que se necesitan fecundidades elevadas para la adecuada reposición de los estocs. Se demuestra cómo los elevados valores de M por edad para los juveniles generados con el modelo recíproco son la contrapartida lógica a la elevada fecundidad que presenta la merluza. El criterio de Charnov sobre el reemplazo intergeneracional del estoc reproductor se utiliza como test para una población sostenible, análogo a un punto límite de referencia que avisa sobre el peligro de sobrepescar a unos niveles que comprometen el reemplazo de la población. Una vez las mortalidades por edad de la merluza de edad 2 exceden $\mathrm{F}(2)=1.1-1.2$, como ocurre actualmente, se pone en riesgo el remplazo del estoc reproductor. La explotación de adultos por los barcos de arrastre cerca de la costa es poco intensa, y las merluzas en proceso de maduración que sobreviven a la red de arrastre migran hacia fondos más profundos alejados de la costa, lo que permite reducir la vulnerabilidad de los juveniles a las redes de arrastre de malla pequeña, y por consiguiente un reclutamiento abundante en los fondos costeros. Las primeras investigaciones sugirieron que los fondos irregulares cerca del borde de la plataforma continental constituyeron un refugio que protegían del arrastre a los reproductores que vivían en aguas alejadas de la costa, permitiendo así un abundante reclutamiento de juveniles cerca de la costa. Esto no es posible si el esfuerzo de pesca en estas zonas alejadas de la costa se ve incrementado de manera incontrolada por el arrastre, las redes de enmalle y los palangres. En este caso, la restauración de estas zonas de refugio para reproductores, y el control de los picos de mortalidad por pesca de juveniles, podría ser una estrategia preventiva dirigida a restaurar los niveles previos de reclutamiento a las redes de arrastre de malla pequeña.

Palabras clave: explotación de juveniles; merluza europea; mortalidad natural por edad; fecundidad de la población; refugio para reproductores; proporción intergeneracional; criterio de Charnov; mar Mediterráneo.

Citation/Como citar este artículo: Caddy J.F. 2015. Criteria for sustainable fisheries on juveniles illustrated for Mediterranean hake: control the juvenile harvest, and safeguard spawning refugia to rebuild population fecundity. Sci. Mar. 79(3): 287-299. doi: http://dx.doi.org/10.3989/scimar.04230.06A 
Editor: J. Lloret.

Received: February 16, 2015. Accepted: May 15, 2015. Published: September10, 2015.

Copyright: () 2015 CSIC. This is an open-access article distributed under the Creative Commons Attribution-Non Commercial Lisence (by-nc) Spain 3.0.

\section{INTRODUCTION}

This study focuses on the mixed species small-scale trawl fishery of the northern Mediterranean capturing immature demersal fishes using the European hake Merluccius merluccius as an example, but has obvious relevance wherever juvenile fish are the focus of a fishery. The study discusses the importance of achieving a balance between the high natural mortality of juveniles, and the high fecundity of a species, which itself must be an evolutionary response to high larval and juvenile predation mortalities.

The predominant gear by tonnage captured, among a wide variety of harvesting methods used, is the finemesh bottom trawl, which has a different catchabilityat-size than large mesh gears. A commonly-used 40- to $50-\mathrm{mm}$ stretched mesh cod end captures a variety of small, high-value organisms including juvenile hake, while sexually mature adult hake are rarely taken. Early observations on distribution patterns and seasonality in the Mediterranean identified life history and seasonal migrations for fish species such as European hake (e.g. Doumenge 1966 - Fig 1A), showing that mature female hake migrate to deeper waters on maturity. Until the mid-1990s, the small-mesh trawl fishery operated sustainably without quotas or strict effort control (Ragonese 2009), and in a retrospective view of the fishery in the mid-1990s, Fiorentini et al. (1997) noted a steady increase in landings of hake and many other species, suggesting that this reflected an increase in recruitment due to the increased productivity of formerly oligotrophic fishing grounds. This environmental phenomenon may explain the anomaly that while landings were increasing, (Fiorentini et al. 1997), assessments of European hake at earlier meetings of the General Fisheries Commission for the Mediterranean (GFCM) documented full to overfished status for Adriatic and Gulf of Lions stocks (see review by Caddy 2012, 2014a). At the $33^{\text {rd }}$ session in 2009, a binding resolution was adopted to reduce fishing effort by demersal trawls by $10 \%$. In recent years, consistently low landings of European hake and other species were documented by Vasilakopoulos et al. (2014), supposedly due to over-exploitation of juvenile fish.

Developing a rational approach to managing fisheries taking juvenile demersal fish is a priority on the global scene. An uncontrolled rise in fishing pressure for many resources has also led to the mean sizes at capture falling significantly (see e.g. Pauly et al. 1998). Up to $20 \%$ or more of juveniles are killed incidentally and/or discarded in global demersal fisheries for adult fishes with no economic benefits resulting (Suuronen 2005, Caddy and Seijo 2011). Discarding small fish is an inevitable consequence of fisheries for mature fish in areas where they mix with juveniles, but the serious impacts of discarding recruits is often discounted.
For example, Section 14.3.2 of the 2014 report of the Working Group on the Assessment of Demersal Stocks in the North Sea and Skagerrak (WGNSSK) for cod, noted that "The variation recorded in year class strength at age 1 is substantially higher than recorded subsequently at ages 2 and 3, indicating that the high rates of discarding (90\%) and high mortality rates at this age are resulting in reduced contributions from one year old fish to the stock and catches". Discarding of small juveniles in Mediterranean fisheries also occurs, but here the age groups discarded are potentially marketable. The results of a forthcoming EU regulation requiring landing of discards will be revealing in all geographical areas. This paper suggests a new approach justifying the harvest of juvenile fishes under conditions in which the mature stock is conserved. It illustrates that the vector of fishing mortality at age in a fishery for juveniles resembles the natural mortality vector in an unfished stock, where the very few fish surviving to spawn have a low natural mortality rate but a high fecundity.

The Mediterranean fleets of small trawlers exploiting juvenile fish resources have been criticized for their low mean age of capture of many species. But, as noted by Ragonese (2009), the "Mediterranean demersal fisheries paradox" of fisheries for juveniles in the past has reflected a relatively stable production regime despite growth overfishing, no quotas, and a generally lax control of fishing effort. Farrugio (2010) reported on 23 stocks of Mediterranean species assessed to date, in which $79 \%$ were overexploited, $18 \%$ fully exploited, and $14 \%$ moderately exploited. For most overfished resources, the current fishing mortalities were from $30 \%$ to over $80 \%$ higher than the optimum effort level, $\mathrm{F}_{0.1}$, assumed by STECF to be equivalent to $\mathrm{F}_{\mathrm{MSY}}$. Catches of these species were mostly juveniles, and had been taken for decades by small-mesh trawls. More recently, 15 Mediterranean demersal and small pelagic fish stocks assessed by the STECF Working Group (STECF 2014) were found to be still overexploited using this criterion. Recent recruitment had declined to one third of that in earlier assessments, the European hake being the most intensively overfished, with ratios of $F_{\text {now }} / F_{\text {MSY }}$ estimated as high as 9.87 and a current $F$ of 1.48 .

From 1990 to 2000, annual yields for immature hake in the NW Mediterranean did not show strong oscillations (data from STECF 2014) although, given the high exploitation rates, criteria from Atlantic assessments of adult fish suggest that these fisheries should have collapsed under a high fishing pressure. On this point however, it may be debated whether the MSY estimates for exclusively juvenile fisheries are comparable with those for fisheries on mature age groups? Although fishing mortalities for ages 2 and 3 are high, so is the age-specific natural mortality rate (e.g. STECF 

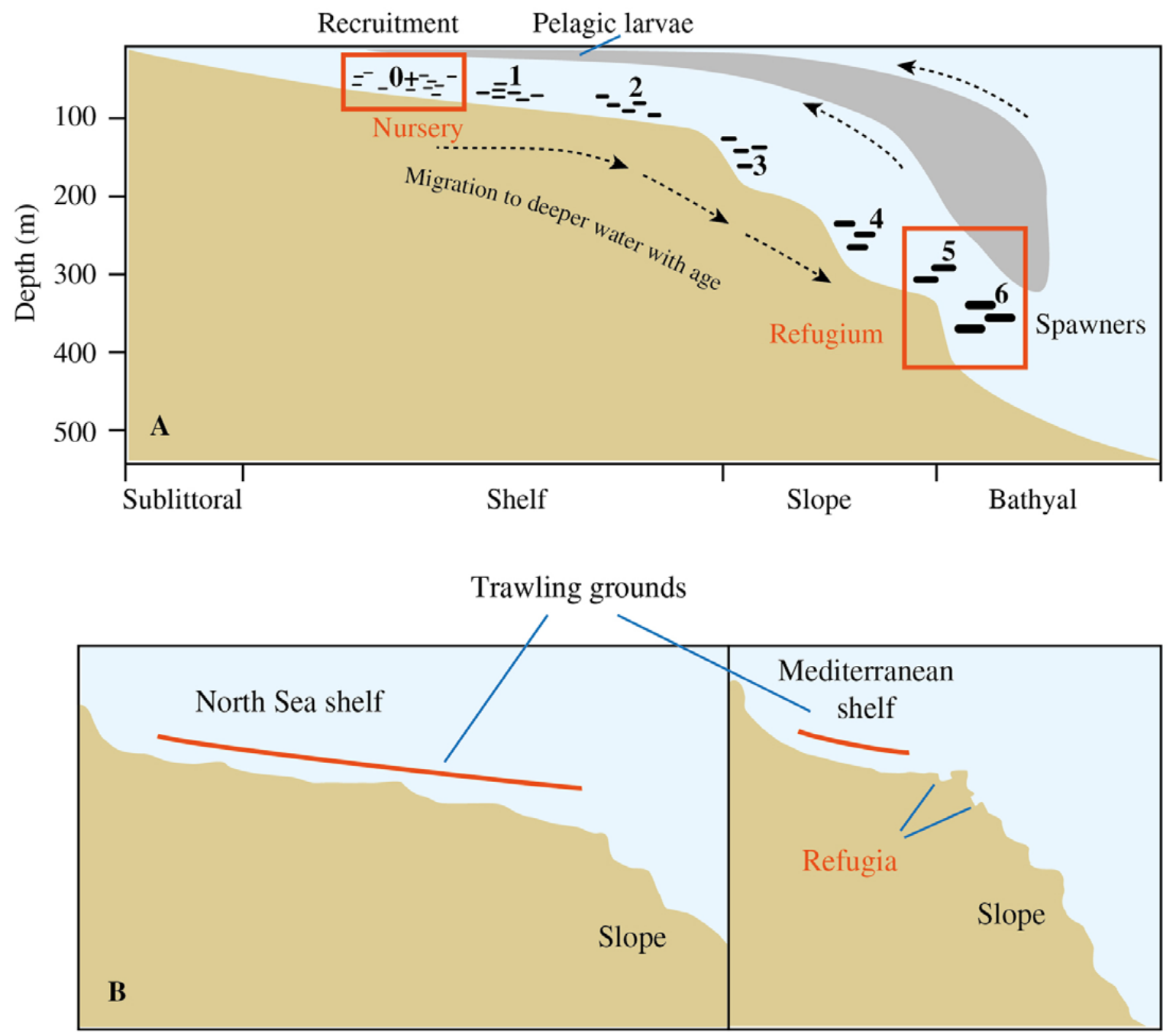

Fig 1. - A, seasonal bathymetric distributions and proposed nursery closures and spawning refugia (red squares) for European hake, stylized as in Doumenge (1966). B, stylized shelf cross-sections for the North Sea and the Mediterranean showing approximate positions of offshore refugia in the Mediterranean.

2014), and for a fishing mortality rate of $F=0.85$ on age 3 fish, the exploitation ratio is only 0.5 , and it drops further for older fishes. One explanation is that the trawl fishery is concentrated on juvenile age classes for a few years only, and then a pronounced decline in catchability occurs as maturity approaches. This may be partly due to the inefficiency of small-mesh, lowheadline trawls for capturing larger fish, as well as the migration of maturing escapees to "spawning refugia" (Fig. 1). Recently Farrugio (2010) described a proposal to exclude demersal and pelagic trawlers, gillnetters and longliners from an offshore "refugium" or Marine Protected Area in the Gulf of Lions.

The configuration of a fishing ground affects the probability of over-exploitation of the spawning stock. In the Mediterranean (see Fig. 1B, and bathymetric charts), untrawlable areas with frequent outcrops occur along the edge of the Mediterranean shelf to a greater extent than in the North Sea. Rising over-exploitation of mature hake stocks may have been the cause of current declines in recruitment, although in the past extensive natural refugia offshore may have provided a "safety valve" for spawners against stock collapse.
Further debate is now required on what the predominant future fishing method should be, and how stock recovery can be achieved? It seems obvious that seeking a maximum yield both from a fine-mesh fishery for juveniles and at the same time from gillnets, offshore trawling and longline fisheries for adults offshore is a recipe for stock collapse. An essential component of self-regulation of the fishery may have recently been removed by allowing fishing on the shelf edge, thus causing a decline in recruitment to inshore trawl landings. Urgent management action now seems to be called for. The first question is, however, how can a fishery for juveniles be assessed?

\section{The bathymetric distribution of hake: is there a migration to a fishery refugium offshore?}

Fisheries investigations in the northern Mediterranean in the early 20th century focused on ontogeny, life history distributions and seasonal migrations. Maturing hake (Fig 1A) apparently migrate offshore to spawn (Doumenge 1966). For the fishery off Viareggio, Italy (Geographical Sub-Area GSA 9), Abella et 
al. (2005) showed that the fleet fishing the shelf inside $200 \mathrm{~m}$ intensely exploits dense schools of juvenile hake, although recent controls aim to discourage local fishermen from harvesting schools of age $0+$ juveniles. It has been questioned whether predator abundance over a heavily-fished ground would be adequate to inflict high juvenile mortalities, but a length-based VPA of local commercial catches using the reciprocal model for $\mathrm{M}_{\mathrm{t}}$ was compared with research trawl surveys in the same time/locality (Caddy and Abella 1999). These two methods both gave similar results for biomass and age composition. Density-dependence could also occur if recruits are subject to trophic limitation, as when dense schools of young fish reduce food availability. Thinning out juvenile hake aggregations by moderate fishing effort might even improve the growth rate of survivors. On this point, Abella et al. (2005) noted the seasonal occurrence of dense aggregations from year to year of age $0+$ hake at $100-250 \mathrm{~m}$, and of age $1+$ fish in shallower water. As suggested by Druon et al. (2012), this spatial/seasonal distribution also provides the basis for closures if a reduction of harvest rate for these first two age groups were agreed to.

Prior to the 1970s, trawling in the northern Mediterranean was mainly on the smooth shallow shelf, where damage to lightly-constructed trawls was low. The shelf edge is too deep, often irregular and unsuitable for small boats using unmodified trawls. More recently, chains and rollers have been added to trawls on larger vessels for use in deeper water on uneven bottom. This has effectively impacted areas postulated to be offshore spawning refugia. In the Spanish offshore areas of the northern Mediterranean, trawling with heavy "rock hopper" gear and other gears aimed at large fish and deep water shrimp have been observed to negatively affect these key habitats, reducing epifauna and displacing sediment down the continental slope (see e.g. Puig et al. 2012). Bellman et al. (2005) illustrated the dense overlay of trawl tracks on complex bottom areas prior to a ban on this type of gear. The subsequent tendency to avoid these areas when trawling with unmodified gear was documented.

\section{The consumer's requirements}

Traditionally, small fish are used in Mediterranean cuisines, and this has suggested that a bioeconomic criterion be used for evaluation (e.g. Caddy and Seijo 2002). Fisheries for juveniles support high-priced traditional dishes of whole young fish, supplied by restaurants in one of the world's top tourist areas. Caddy and Seijo (2002) noted the marked contrast between the reproductive value of different-sized female hake and their economic value. Thus, while a restriction of fishing pressure on age 1+ fish is strongly recommended, market demand and bioeconomic analysis seem to favour targeting juvenile hake and conserving spawners, since catches of juveniles, small fish and invertebrates caught incidentally all command high prices on local markets. This supports the conclusion that it might be possible to achieve an economic optimum (e.g. Caddy and Seijo 2002) with properly- managed fisheries on juvenile European hake, even if this did not coincide with an MSY. High prices are asked for young hake retailed in Italy and in France (as an example, in January 2015, the retail price for age 1 and 2 fish (17-22 cm total length) in a supermarket near Rome was $17.50 € / \mathrm{kg}$, personal observation). Reproductive value increases with size, while the unit landed value generally decreases with size in northern Mediterranean ports. Until the 1970s-1980s, the trawl fishery was focused on juveniles prior to reproductive age (4-5 y), and the few fish escaping to maturity from the fine-mesh trawl fishery apparently migrated further offshore to spawn.

\section{Are conventional assumptions on stock assessment compatible with a fishery for juveniles?}

As a source of methodologies for analysing agestructured data, Beverton and Holt (1957) influenced stock assessment approaches world-wide. Their work supports constant parameter yield/recruit calculations, and although their methodologies have been modified in a few areas and for a few species (e.g. where higher natural mortality rates for juveniles are now applied), the theoretical basis for the assessments they proposed is still widely accepted. Constant parameter-at-age models were used after WWII when North Sea fisheries in the late 1940s and 1950s took a dominant proportion of the adult fish accumulated on the grounds, following five years of low fishing effort during hostilities. For exploitation of mature fishes, a constant $\mathrm{M}$ assumption is of course tenable, but the constant $\mathrm{M}$ assumption continues to be used in assessing many fisheries taking juveniles offshore from developing as well as developed countries, and in mesh size calculations.

Returning to fisheries science in the 1990s, Beverton (1992) commented on the way fisheries science has misinterpreted his joint work with Sidney Holt. Recognizing that fisheries science must pay more attention to events in the early life history, he noted that "The proportion of the total amounts of fish consumed that is eaten by other fish... sea mammals and birds is as great or greater than it is by man". In fact, it is rare for current assessments of demersal resources to collect and use information on fecundity and larval and prerecruitment mortalities. Fitting a stock recruitment relationship (SRR) in which recruitment success is used as a function of the size of the spawning stock is the standard approach. As noted by a referee for this paper, when data are available, the SRR procedure often illustrates the unpredictability of recruitment success as a function of spawning stock size. However, precautionary concerns should come into play when the spawning stock is low, as in the case discussed here.

According to Kolding and van Zwieten (2011), two reasons are given in the classical literature to concentrate on size and age in fisheries management:

Juvenile fishes should realize their "growth potential" (Petersen 1894) before capture.

The "Propagation Theory" requires that all fish in a stock be given a chance to arrive at the size for reproduction before capture. 


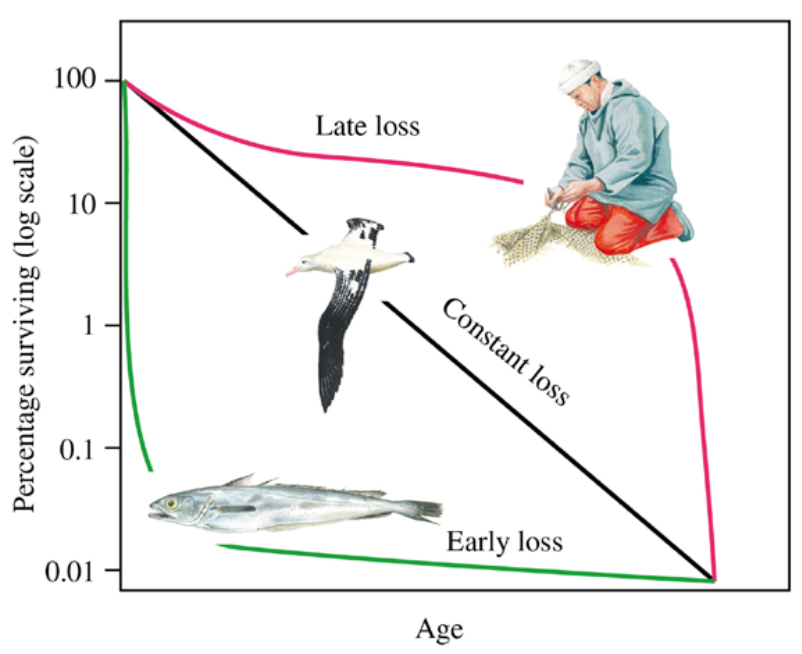

Fig. 2. - Generalized survivorship curves typical of mammals (e.g. fishermen), birds, and European hake (modified after Larkin 1978 and Kolding and van Zwieten 2011). The prevailing mortality pattern a species follows shapes the life history strategy, and should be taken into account in harvesting. Fish have a very high fecundity, but the vast majority of juveniles die long before adulthood. (On the other hand, fishermen [and other mammals!] may live much longer than fishes, and instinctively protect the few offspring they produce!).

The Propagation Theory implicitly assumes that fish follow the same type of survivorship curve with age as mammals and birds. This is unlikely to be correct, as illustrated by Figure 2 in which the generalized survivorship curves for mammals, birds, and bony fish were contrasted by Larkin (1978). Bony fish are often highly fecund, so the vast majority of juveniles must die of natural mortality long before reaching sexual maturity. However, the life strategy of highly fecund organisms is often misunderstood within "The Theory of Fishing". Quoting Kolding and van Zwieten (2011): "We are mammals, surrounded by mammals, and see the world through mammal eyes"; i.e. from our personal experience as mammalian parents with few offspring, we instinctively give priority to conservation of young stages. This neglects evidence for the high natural mortalities in young fish and invertebrates, and may result in overoptimistic estimates of increased yield with larger mesh sizes from given levels of recruitment. With respect to the impacts of trawls on escaping juveniles, careful studies on survival of juvenile fish after escapement through trawl cod ends (e.g. Sangster and Lehman 1993, Erikson et al. 1999) showed that indirect mortality from trawling may range from $14 \%$ to over $40 \%$ of the escaping or escaped juveniles. Experimental studies also showed that after passing through the cod end, juveniles are stressed and liable to physiological exhaustion (Chopin and Arimoto 1995) and to predation in a weakened state (e.g. Suuronen 2005). Equally important are measures to conserve the older spawning stock, although these are rarely applied. Hixon et al (2014) also demonstrated that older spawners make a higher contribution to future generations in terms of fecundity and egg viability than first spawners, and merit protection by closed areas or other measures.

The top priority given to conservation of juveniles as opposed to spawners in fisheries for adults is associated with an erroneous "constant M" assumption. On this point, McCoy and Gillooly (2008) showed that an increase in body size reduces the natural mortality rate for both plants and animals, and Lorenzen (1996) recognized that this generalization also applies to fishes. Several authors have generated age-specific values, $\mathrm{M}_{\mathrm{t}}$, as in the Multi-Species Virtual Population Analysis (MSVPA) in the North Sea, and also in modelling by Powers (2014). Simple approaches to estimating juvenile Ms-at-age are infrequently used, but give similar results, and Ragonese et al. (2006) provided a comprehensive summary of such methodologies. The $\mathrm{M}$-at-age vector should reflect the high levels of natural mortality for juveniles, and the reciprocal mortality function (Caddy 1991, Abella et al. 1997) achieves this result. This model has been described (Di Natale et al. 2009) for assessments of Mediterranean groundfish juveniles, but has not been used for North Sea stocks. The model indirectly reflects density-dependent mortality on juveniles, since a high level of natural mortality may also be a response to limited food resources. If recruits are vulnerable to trophic limitation, high densities of young fishes will reduce food availability.

The lower predation rates for adult fish have long been recognized, but the fundamental question is, should juveniles really be harvested? Adjusting harvesting intensities in a mixed species fishery to reflect the range of natural mortality rates of the species harvested was considered ideal by Caddy and Sharp (1986), and this strategy has since been referred to as "balanced harvesting" (e.g. Norris 1991, Quaas et al. 2013). Arguably, where age-specific fishing mortality rates track trends in $\mathrm{M}$-at-age, and a virtual population analysis shows sharply declining Fs with age, a natural refugium may exist for larger individuals. In this case, an aimed fishery for juveniles may be more easily supported by the stock than if a fishery is aimed at the very few adults reaching maturity.

\section{A more detailed description of predation risk in fisheries for juveniles}

Ideally, the first question to address is whether the survival rate to sexual maturity will be adequate for population continuity? Egg production of highly fecund species is not usually seen as a constraint on recruitment, but when coupled with the reciprocal mortality model, the need for conservation of population fecundity becomes more evident. The majority of a new cohort is consumed by predators early in life, and discarding also reduces the abundance of pre-recruits.

Events in the period from spawning to recruitment in many adult fisheries (often with partial exploitation starting at ages 2 to $3+$ ), are critical to proper management, but not easily investigated. Calculations of survival rates from egg to maturity are rare, and indirect approaches to estimation often bypass the egg, larval and post-larval stages by using an SRR (e.g. Mangel et al. 2013), in which direct information on the early life history from egg to recruitment is not needed. SRRs developed by Beverton and Holt, or the alternative by Ricker (1958), are not currently available for most Mediterranean resources where long time series of age 

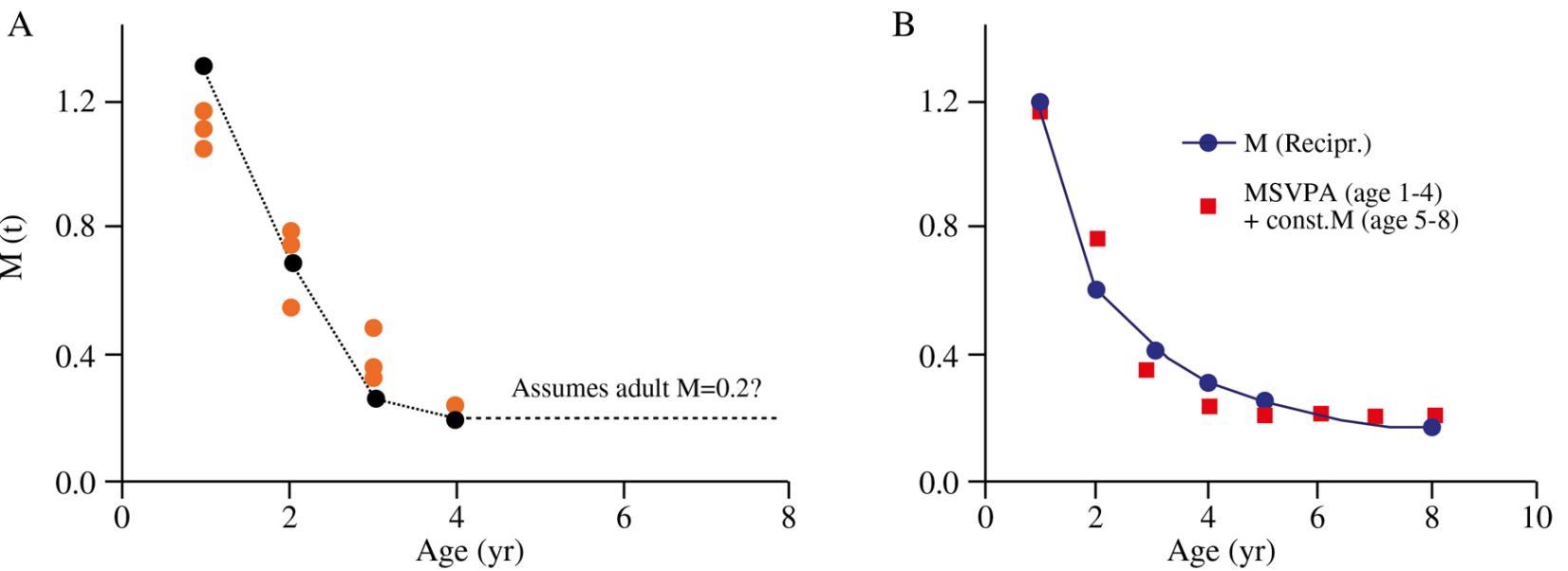

Fig. 3 - A, using the reciprocal model to fit Ms-at-age for North Sea cod of ages 1-4 incl. (yellow circles) (data from Table 14.5B in ICES 2014). B, a comparison is made using MSVPA cod data from ICES (2014) for ages 1-8 (mean values for 1963, 1980, 2013). A fitting to mean values of this data set by the reciprocal model is shown (for $\mathrm{A}=0.004 ; \mathrm{B}=1.185$ ). (A constant $\mathrm{M}=0.2$ was apparently assumed in ICES [2014] for $\mathrm{M}_{\mathrm{t}}[\mathrm{t}=5,6,7,8]$, independently of natural mortality estimates for younger fishes).

compositions are rare, and small adult catches of some species are made.

Studies carried out on hake biology (e.g. Bozzano et al. 1997, Carpentieri and Colloca 2005) showed that cannibalism is an important dietary source for large hake, but Payne et al. (1987) noted that small hake are rarely found in the vicinity of adults, due to size segregation by depth. Nonetheless, the main ecological role of most offspring will be to contribute trophically to the local ecosystem. This is consistent with ecosystem theory: high juvenile mortality means that small organisms make up a large component of fish food, a feature not always represented in those ecosystem models which use adult values of $\mathrm{M}$ in their simulations.

\section{METHODS}

\section{Choosing a useful approximation to M-at-age $\left(M_{t}\right)$ for juveniles}

The MSVPA experiments in the North Sea estimated the age structure of small fish found in the stomachs of predators, and showed that predation rates on small fish are very high (Sparholt 1990). Stomach sampling of predators using the MSVPA procedure is apparently still used to obtain M-at-age for juvenile cod in the North Sea (see ICES 2014) but rarely elsewhere, perhaps because of the substantial research effort needed to collect, identify and determine ages for prey species in stomachs. One of the few data sets allowing a comparison of the predictions of the reciprocal model was the natural mortality rate estimated from age compositions of the first four age classes of cod sampled from stomach contents of predators (ICES 2014). A portion of this data set was fitted using the PROBIOM procedure (Abella et al. 1997), together with growth data for cod from Abella et al. (1995) and length-weight information from Arnason (2009). Figure 3A compares juvenile $M_{t}$ estimates for North Sea cod in ICES (2014) with their best fit using the reciprocal model. The procedure for obtaining an $\mathrm{M}_{\mathrm{t}}$ vector with PROBIOM minimizes the difference for all age groups between collective age-specific values of overall biomass losses (OLB) and overall production, using the SOLVER routine of EXCEL. In Figure 3B, a comparison is made with MSVPA data for cod, including $M$ values for adult fish, where constant $M$ appears to have been assumed for older fishes in the MSVPA plot. Unlike the ICES (2014) data, the reciprocal model shows a slow decline in $\mathrm{M}_{t}$ for older, larger fishes, which is consistent with predation theory. Figure 4A and B shows the fitting of the MSVPA data for M-atage of cod, using the reciprocal relationship (Caddy 1991, Abella et al. 1997), where

$$
\mathrm{M}_{\mathrm{t}}=\mathrm{A}+\mathrm{B} / \mathrm{t}>0, \mathrm{t}=\text { age, and } \mathrm{A}, \mathrm{B} \text { are constants. }
$$

\section{Yield/recruit and fecundity/recruit models for European hake}

To assess $\mathrm{Y} / \mathrm{R}$, the reciprocal model for natural mortality was combined with different vectors of $\mathrm{F}$ in calculations of Thompson and Bell (1934), where the relative Fs-at-age correspond to the vector of fishing mortality at size found by Caddy and Abella (1999). These results were compared with similar life history calculations using the same $F$ vector and number of age $0+$ recruits, but an assumed constant value of 0.2 for M-at-age (Fig. 4A). To test the effect of different levels of juvenile fishing mortality on yield and fecundity/ recruit, the original $\mathrm{F}$ vector from Caddy and Abella (1999) was scaled to represent progressively intensifying fishing mortalities on the population (Fig. 5), with relative Fs-at-age peaking at 1-2+ y (see Fig. 6A). These F-vectors, with relative Fs-at-age, were used to calculate yield/recruit and fecundity/recruit for different levels of overall fishing intensity. Egg production/ female for survivors of this second generation, once mature, was accumulated over all mature ages for each vector of F-at-age, and the mean size captured, the yield/recruit, and the ratios of juveniles surviving were compared with the previous generation. 

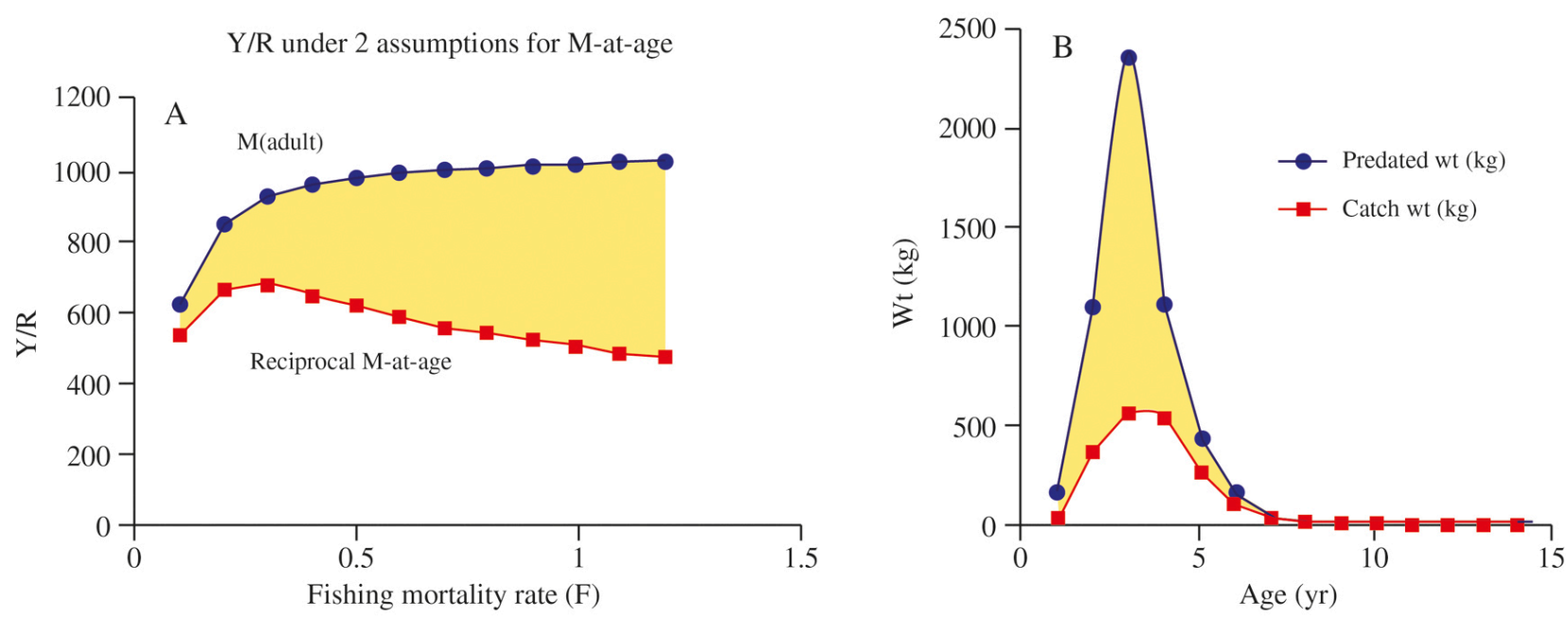

Fig. 4. - A, when assuming a constant $M$-at-age $(M=0.2)$, the hypothesized $Y / R$ is much higher than with the reciprocal model (for the same number of recruits in both cases). In contrast, with the reciprocal model the mean M-at-age decreases with decreasing F-at-age. Thus, fishing juvenile Mediterranean hake harder than $\mathrm{F}=0.3-0.4$ will result in little extra yield under the reciprocal $\mathrm{M}$ option. $\mathrm{B}$, using the reciprocal M vector, most of the early deaths are due to predation (yellow), and this explains the lower Y/R with the reciprocal model for the same number of recruits (data from Viareggio; Abella et al. 2005).

\section{Charnov's diagnosis for a stable population}

For stable populations, Charnov (1993) proposed that a mature female must produce enough eggs so that at least one female in the next generation survives predation to reproduce. The reciprocal equation for $\mathrm{M}_{\mathrm{t}}$ is equivalent to a high level of mortality on juveniles, so while a female may lay over $10^{5}$ eggs per year, very few adult female survivors will result (Table 1). Calculations of fecundity/recruit using a low and constant $\mathrm{M}$ make no sense here: too many recruits would survive, which would lead to a population explosion or a die-off in the absence of adequate food. If the fishing strategy respects the Charnov criterion, then equality between the fecundity of successive generations of mature females could be a useful theoretical limit reference point for a sustainable juvenile fishery (Caddy 2014b). In other words, if a long-term ratio of $1: 1$ is exceeded between the abundance of the maternal generation and its progeny at the same life history stage, then under the assumptions followed here, this is predicted to result in a growing population (Table 1), and vice-versa. Given the typically high variance in intergenerational survival, this approach is not necessarily predictive annually, but (as in a Y/R calculation) is of broad explanatory value.

To test compliance with Charnov's criterion for population stability, a fixed number of female age $0+$ fish was simulated through to the maximum age $(15 \mathrm{y}$ assumed), using the parameters of the reciprocal mortality model $(\mathrm{A}=0.142: \mathrm{B}=1.403)$ fitted for hake by Abella et al. (1997). The annual numbers of eggs spawned by a mature female at each mature age came from Cesarini (1994), and spawning was assumed to start at age 5. Individual egg production-at-age was multiplied by the survivors-at-age predicted by the reciprocal equation, before summing annual fecundities over the reproductive life span. From an independent estimate of planktonic survival for larvae of another hake species, the order of magnitude of female progeny reaching the next generation as $0+$ recruits after the planktonic stage, was assumed to be $3-5 \%$ of the eggs spawned. These figures for larval survival came from the Cape hake (Garavelli
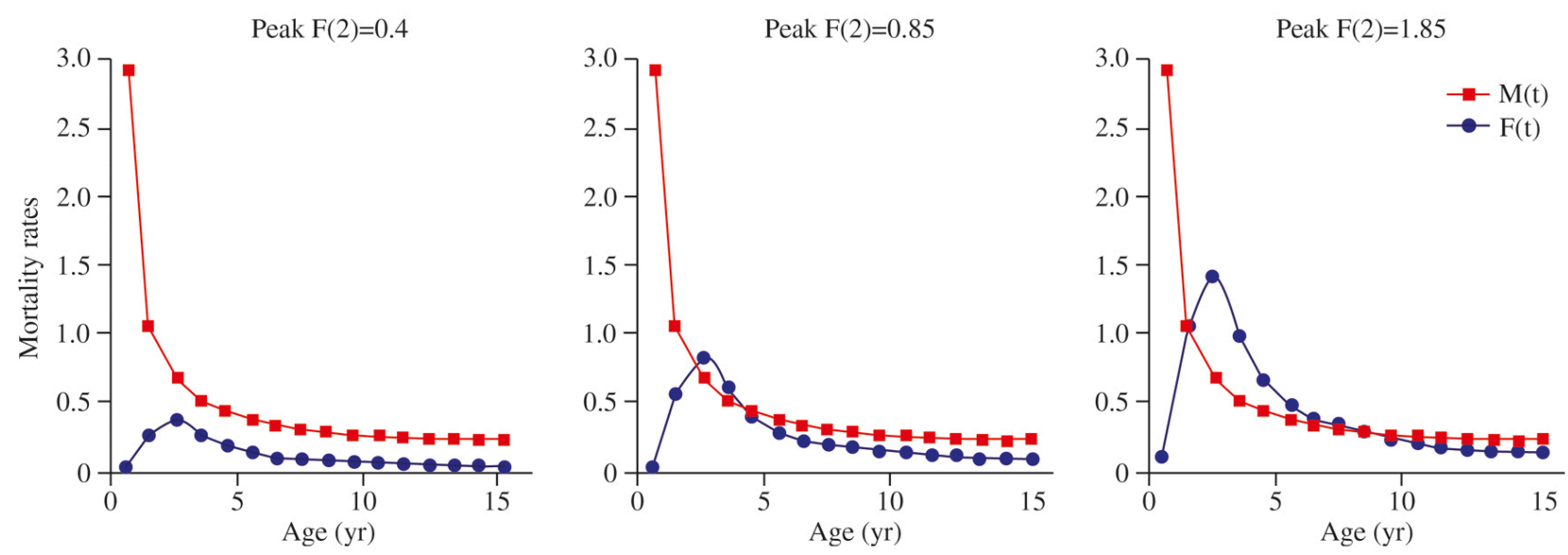

Fig. 5. - Trajectories of fishing mortalities at age corresponding to 3 peak fishing mortality rates. With the exception of high peak $\mathrm{F}(2)=1.85$, after age 2 , the fishing mortality rate at age closely tracks declining $\mathrm{M}(\mathrm{t})$. 
Table 1. - Illustrating the calculations underlying Figure 6. Yield from 50000 age $0+$ females was accumulated with age for each vector of F-at-age used (examples given in Fig. 5). Full maturity at age 5 is assumed. The table illustrates a calculation of fecundity (assuming a 1:1 sex ratio), i.e. eggs produced in their lifetime by survivors of 50000 age $0+$ females of the maternal generation after they begin spawning at age 5. At this time they were subject to an annual fishing mortality vector with peak $F(2)=0.85$ of the form shown in Figure 6 A. The planktonic survival of eggs to age $0+$ female recruits in the next generation is subject to one of two survival rates in the plankton, i.e. $3 \%$ or $5 \%$.

\begin{tabular}{|c|c|c|c|c|c|c|c|c|c|}
\hline $\begin{array}{l}\text { Mid-Pt. } \\
\text { Age }\end{array}$ & $\begin{array}{c}\text { Individual } \\
\text { fecundity-at-age }\end{array}$ & $\begin{array}{l}\text { Ms at } \\
\text { age }\end{array}$ & $\mathrm{F}$ vector & Surv. Rate & $\begin{array}{l}\text { \# females } \\
\text { surviving }\end{array}$ & $\begin{array}{c}\text { \# eggs } \\
\text { spawned }\end{array}$ & $\begin{array}{c}\text { Catch } \\
(\#)\end{array}$ & Indiv. wt (kg) & $\begin{array}{c}\text { Catch } \\
\text { (kg: females) }\end{array}$ \\
\hline 0.5 & 0 & 2.95 & 0.10 & 0.05 & 2372.7 & & 1563 & $0.00+$ & 1.4 \\
\hline 1.5 & 0 & 1.08 & 0.60 & 0.19 & 443.5 & & 690 & 0.02 & 15.5 \\
\hline 2.5 & 0 & 0.70 & 0.85 & 0.21 & 93.9 & & 191 & 0.09 & 17.2 \\
\hline 3.5 & 0 & 0.54 & 0.60 & 0.32 & 29.9 & & 34 & 0.21 & 7.1 \\
\hline 4.5 & 0 & 0.45 & 0.40 & 0.43 & 12.8 & & 8 & 0.39 & 3.1 \\
\hline 5.5 & 362114 & 0.40 & 0.30 & 0.50 & 6.4 & 2301064 & 3 & 0.61 & 1.7 \\
\hline 6.5 & 500222 & 0.36 & 0.23 & 0.56 & 3.5 & 1766478 & 1 & 0.86 & 0.9 \\
\hline 7.5 & 638997 & 0.33 & 0.22 & 0.58 & 2.0 & 1303616 & 1 & 1.14 & 0.7 \\
\hline 8.5 & 772407 & 0.31 & 0.20 & 0.60 & 1.2 & 949397 & 0 & 1.43 & 0.5 \\
\hline 9.5 & 896636 & 0.29 & 0.15 & 0.64 & 0.8 & 710280 & 0 & 1.73 & 0.3 \\
\hline 10.5 & 1009604 & 0.28 & 0.15 & 0.65 & 0.5 & 522741 & 0 & 2.02 & 0.2 \\
\hline 11.5 & 1110494 & 0.26 & 0.11 & 0.69 & 0.4 & 395723 & 0 & 2.32 & 0.1 \\
\hline 12.5 & 1199347 & 0.25 & 0.13 & 0.68 & 0.2 & 291148 & 0 & 2.60 & 0.1 \\
\hline 13.5 & 1276743 & 0.25 & 0.12 & 0.69 & 0.2 & 215040 & 0 & 2.86 & 0.1 \\
\hline 14.5 & 1343575 & 0.24 & 0.11 & 0.71 & 0.1 & 159728 & 0 & 3.11 & 0.0 \\
\hline \multirow[t]{2}{*}{15.5} & 1400881 & 0.23 & 0.10 & 0.72 & 0.1 & 119476 & 0 & 3.35 & 0.0 \\
\hline & & & & & & & 2491 & & 48.9 \\
\hline
\end{tabular}

Summary:

- Lifetime \# eggs produced by survivors of 50000 age $0+$ recruits of the maternal generation $=8734691$ eggs.

- Mean \# eggs for each age $0+$ recruit of the maternal generation $=174.7$

- Lifetime \# hatching as females (50:50 sex ratio assumed) $=87.3$

- If $3-5 \%$ of female larvae survive planktonic life, the larvae surviving to the next generation at age $0+=2.6$ to 4.4 individuals.

et al. 2012), and were used in the absence of similar studies on M. merluccius larvae. The number of female $0+$ progeny surviving planktonic life was compared with the initial number of $0+$ female recruits from which survivors to maturity formed the maternal generation.

\section{RESULTS AND DISCUSSION}

\section{Yield per recruit and egg per recruit comparisons for small hake}

A characteristic of fine-mesh trawls is that they take few European hake over 2-3 years of age. Ragonese (2009) suggested that this may be a feature of finemesh trawls with a low headline, but a key question is whether larger fish are actually on the fishing grounds used by fine-mesh trawls?

Yield/recruit and calculations for European hake were implemented, assuming harvesting starts at age $0+$. The reciprocal $\mathrm{M}(\mathrm{t})$ declines sharply from a high on age $0+$ juveniles, to a value for older fish close to $\mathrm{M}$ (adult) $=0.2$, similar to that used in "constant M" calculations. Under the reciprocal $\mathrm{M}$ assumption, a minor decline in $\mathrm{Y} / \mathrm{R}$ will occur with moderate increases in fishing mortality.

The results of calculations with a range of different fishing mortality rates at age are shown in Figure 6. At a peak of $F=1.45$, the juvenile fishing mortality rate $F_{t}$ just exceeds $M_{t}$ for age 2-4 fish, but for lower fishing intensities and other age groups this is not the case. Catches consist in part of those juveniles, which if unexploited, would soon have been predated. The fishing mortality on age $1+$ is already relatively high (Fig. 6A) due to harvesting of dense schools of young hake, although this practice is being discouraged near Viareggio (Abella et al. 2005). For ages 3+ (Fig. 6A), the fishing mortality in this locality declines mark- edly with age, which as noted, may be characteristic of fisheries where a refugium is in place. The fishing mortality rate on immature fish is predicted to remain at or below the predation rate, as illustrated by the agespecific exploitation ratio: $E_{t}=F_{t} /\left(F_{t}+M_{t}\right)$ in Figure 7 .

Given the high rate of predation, the predicted $\mathrm{Y} / \mathrm{R}$ with a reciprocal $\mathrm{M}$-at-age is substantially lower for the same number of $0+$ recruits than if calculations assumed constant M (Fig. 4A). However, Y/R calculated with the reciprocal model declines slowly with fishing mortality, and peaks at around age 2 . In contrast, a sharp decline in population fecundity is predicted to occur with rising fishing mortality, as shown by the insert in Figure 6B. Here, a 1:1 intergenerational ratio is predicted to occur for the two assumed levels of larval survival, at between $\mathrm{F}(2)=1.2$ and 1.3 (i.e. below the current level of $\mathrm{F}=1.48$ estimated by STECF 2014). This suggests that at the current level of $\mathrm{F}$, adequate stock replenishment is not occurring. The insert on Figure 6B also shows a precautionary (yellow) range for peak Fs, extending down to an arbitrary low at $F(2)=0.7$. The two descending lines plotted against peak $\mathrm{F}(2)$ in the fishing mortality vectors of Figure $6 \mathrm{~B}$ correspond to predicted replacement ratios of the ratio (maternal abundance at age $0+$ ) : (abundance of offspring at age $0+$ ) of 1:3 and 1:6 for the $5 \%$ and $3 \%$ respectively, of the larval survival predicted in the plankton. The value to aim for in a recovery plan would be a sufficiently high replacement ratio, perhaps of an order of magnitude of about $1: 3$ to $1: 6$ ?

In conclusion, Figure 6B shows that the critical motive for controlling fishing pressure on juveniles would be to improve survival to recruitment, not primarily to maximize the yield extracted. In fact, the Y/R of juveniles is relatively impervious to modest changes in fishing pressure, given that fish sizes captured are 

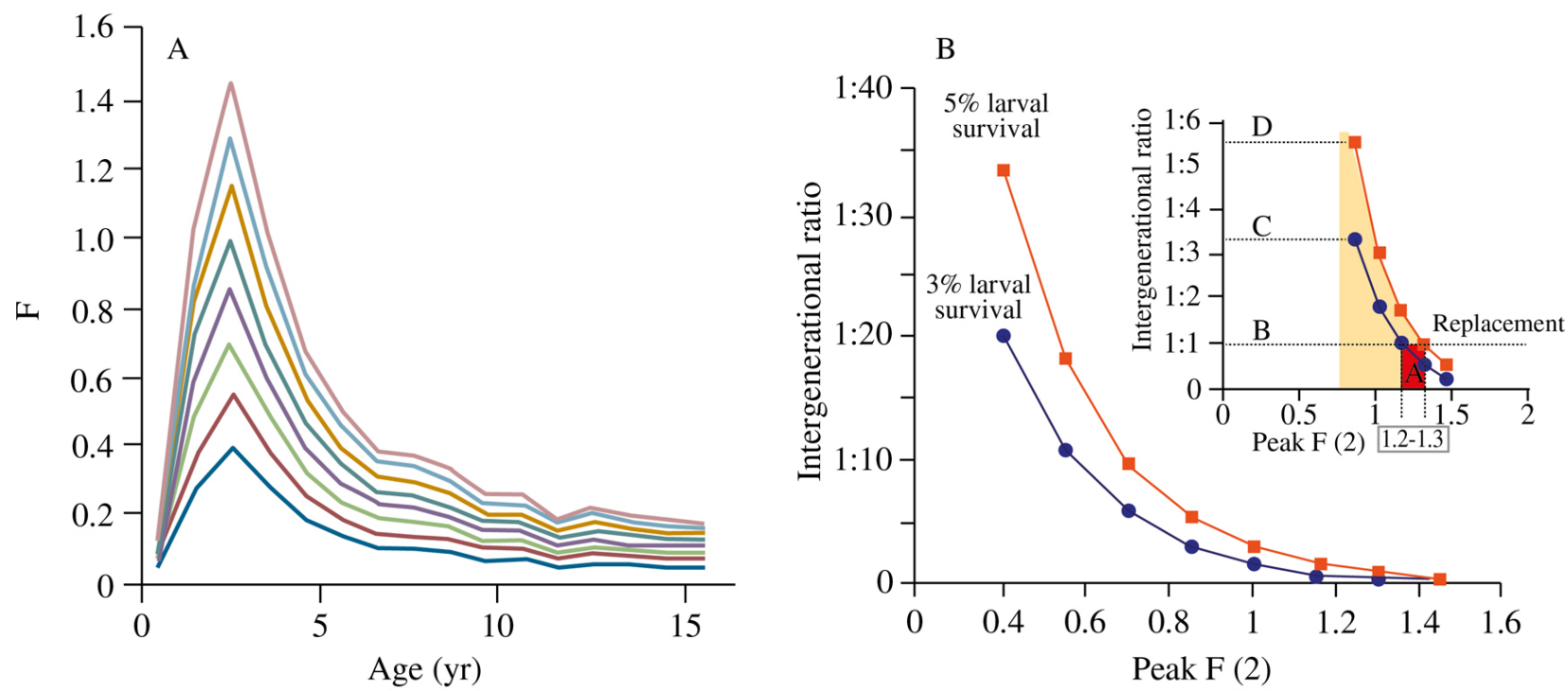

Fig. 6. $-\mathrm{A}$, F vectors with age, ranging from peak $\mathrm{F}(2)=0.4-1.45$, used for simulating life history survival and joint fecundity of mature age groups, leading to estimation of intergenerational ratios of female hake juveniles of age $0+$. B, predicted replacement ratios with peak $\mathrm{F}(2) \mathrm{s}$ for 3\% and 5\% larval survival in the plankton. The inserted graph shows peak F(2)s at around 1.2-1.3 (along line B: marked "Replacement"), where $3 \%$ and $5 \%$ larval survival results in a $1: 1$ ratio of age $0+$ progeny relative to those in the maternal generation. Line $\mathrm{C}$ shows the trajectory of ratios for $3 \%$ survival, and line $\mathrm{D}$ for $5 \%$ survival, for different peak $\mathrm{F}(2)$ s. The yellow area from $\mathrm{F}(2)=0.7$ to 1.2 is a precautionary zone, suggesting that a recovery programme be applied with a peak $\mathrm{F}(2)$ reduced to around 0.7 , which is predicted to result in intergenerational ratios in the range 1:3 to $1: 6$.

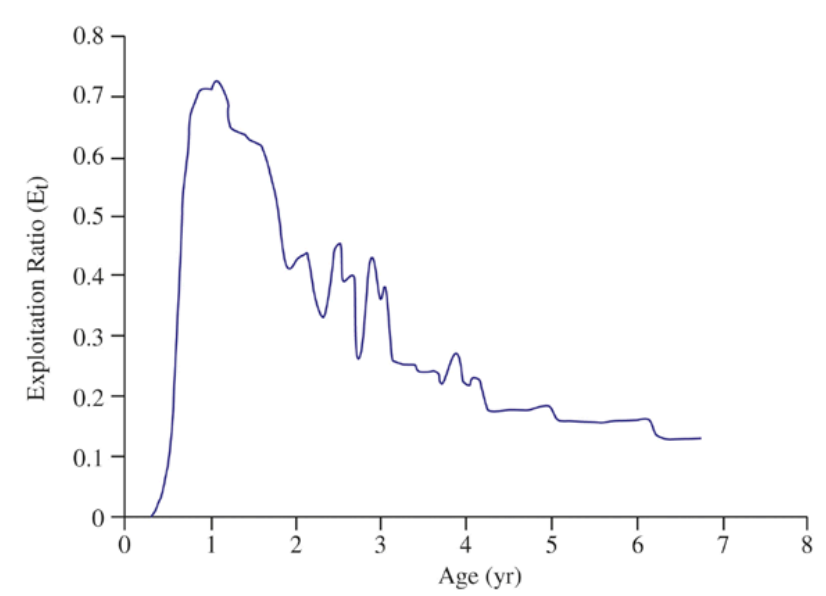

Fig. 7. - The exploitation ratio $\mathrm{E}(\mathrm{t})$ is not a constant when age-specific values $F_{t}$ and $M_{t}$ are used. After peak exploitation at ages 1-2, there is a declining and relatively low rate of exploitation for maturing and mature European hake (Data from A. Abella, pers. comm.).

predicted to decline when a higher fishing intensity catches them earlier in life with a higher mean $\mathrm{M}_{\mathrm{t}}$. Thus, there is no advantage gained from a high level of juvenile fishing mortality.

\section{A retrospective view on Mediterranean demersal fisheries in the northwestern Mediterranean}

A retrospective view of events in Mediterranean demersal fisheries seems useful, given that Vasilakopoulos et al. (2014) commented on the lack of effective action in managing Mediterranean demersal resources. Catches of many Mediterranean species reported by the GFCM peaked in the late 1980s and early 1990s, and have declined since then. Mediterranean hake landings were highest in 1990 at over 52000 tonnes, but had fallen by half by 2002. In 2009-2010, the GFCM again considered that hake stocks were overexploited, and in particular, the spawning stock. In consequence, conservation groups have called for restrictions on areas fished, and the elimination of gear modifications which allow trawling over biologically sensitive areas (positive effects of such a prohibition was documented in US waters by Bellman et al. 2005). Targeting the foraging arenas surrounding untrawlable bottom may catch more fish, but lost netting added to outcrops continues to "ghost fish" (e.g., Link and Demarest 2003), further depleting stocks.

That a fishery for juveniles was accompanied by some protection of the spawning stock by refugia in deeper waters is a key explanatory element for the continuity of production by the inshore trawl fishery in the 1970s-1990s. During the 1980s-1990s, landings of Mediterranean demersal species were steadily rising (see Fiorentini et al. 1997), while paradoxically, assessments presented at GFCM over the same period showed full to over-exploitation of hake stocks. In response to this conundrum, investigations by Caddy (1993, 2000), and De Leiva Moreno et al. (2000) drew attention to an increase in productivity of the semi-enclosed Mediterranean Sea, accompanied by a transition from oligotrophic to mesotrophic conditions in the Gulf of Lions and Adriatic, which now receive high nutrient runoff from rivers. It seems reasonable to conclude that overall increases in recruitment over this period were responses to favourable trophic and environmental inputs: perhaps somewhat comparable to the gadoid outburst in the North Sea cod stocks in the 1970s caused by environmentally-driven changes in food abundance 
(Hislop 1996). It would not be surprising therefore, if at the time, national management authorities saw implementation of strong corrective measures as less than urgent, despite assessments showing over-exploitation.

This paper is unable to answer the question as to whether environmental factors are also in part responsible for recent declines in recruitment, or is overfishing the sole cause? The exploitation rate at age described for the "Mediterranean paradigm" parallels the trend in natural mortality at age, in that both the exploitation rate and the natural mortality rate are high for juveniles, but drop to much lower levels for mature fish. In other words, fishing mortality at age parallels natural mortality at age: a strategy with a lower impact than the Beverton and Holt approach, where adult fish are targeted and juveniles supposedly conserved (if indirect fishing mortalities and deaths due to discarding can be ignored). Targeting of the spawning stock is contrary to the declining trend in predation mortality with age normally seen in nature, and places the few spawners surviving in a heavily exploited population at risk of reproductive overfishing if errors are made in assessment or management. As noted by Hixon et al. (2014), "Fishing differentially typically resulting in severe truncation of the size and age structure of the population [...] acting as a powerful selective agent. Age truncation is now known to destabilize fished populations, increasing their susceptibility to collapse".

\section{Seasonal bathymetric distribution of demersal fish: is there an offshore migration to a fishery refugium?}

Evidence points to a characteristic of fine-mesh trawls in not taking many hake over 2-3 years of age, which Ragonese (2009) suggested to be a feature of fine-mesh trawls with a low headline height, but the key question is whether larger fish are on the trawling grounds? The hypothesis of gear inefficiency in not capturing large hake cannot be eliminated, but an offshore migration on maturity may be a major causative factor (see Figs 1 and 4). Also, the fishing mortality estimates obtained by virtual population analysis decrease markedly with age to low fishing mortalities (e.g. Caddy and Abella 1999, Aldebert and Recasens 1996). As noted, these issues point to a spawning refugium in operation, which was defined by Anthony and Caddy (1980) as a combination of locality and gear performance that protects critical life history stages. When discussing the effectiveness of refugia, I refer to the opinion of Carl Walters, quoted in Orensanz and Jamieson (1998): "If we look at fisheries that have been successful over the long term, the reason for their success is not to be found in assessment [...] models, but in the existence of a spatial accident [...] that creates a large-scale refuge for a substantial segment of its spawning population."

The "refugium paradigm" suggests that the few fish surviving to maturity after escaping the fine-mesh trawl fishery eventually migrate offshore to spawn. In fact, spatial data for the distribution of fishing gears (e.g. Aldebert and Recasens 1996) showed that areas close to the shelf edge are less vulnerable to fine-mesh trawls, but still vulnerable to set nets or longlines. A spawning stock should also receive some protection there from intensive trawling, as in Italian waters, where a ban on the use of extra chains and large rollers is in place. Without this modification, it would be hazardous to trawl near the shelf edge. However, in Italian waters, most large hake are taken with hooks and set nets down to $400 \mathrm{~m}$, and if the hypothesis illustrated in this paper applies, fishing there with all gears aimed at mature fishes should be controlled.

\section{Some key management issues}

The conventional solution to improved demersal fish management in the Mediterranean has been to call for increases in the cod end mesh size and to close nursery areas to fishing. Such a strategy may risk diverting effort onto the depleted component of mature fish, and would lose catches of valuable small species of cephalopods and shrimp only captured by small-mesh gears. From Y/R calculations with the reciprocal model, any increase in yield as a result of a larger mesh size would be at best modest, and might increase the vulnerability of spawners to capture.

While the hake fishery in the Mediterranean seems particularly resistant to heavy exploitation, its current status appears to correspond to both an overexploitation of juveniles and a likely depletion of the spawning stock. A management approach suggested here is to maintain spawning production at safe levels by significantly reducing fishing effort on certain offshore grounds described as "refugia" where spawners are regularly encountered, while also strongly limiting trawling effort inshore on juveniles. A suggestion would be to aim for a peak fishing mortality on juveniles not greatly exceeding $F(2) \approx 0.7$. Supplementary closures could also be used to protect nursery areas. This approach to management seeks to restore "the Mediterranean paradigm" described by Ragonese (2009). It is potentially relevant for demersal fisheries elsewhere, especially if high exploitation rates have reduced the mean fish size so that juveniles predominate.

Vasilakopoulos et al. (2014) suggested that limiting juvenile exploitation, implementing management plans, and strengthening compliance, control and enforcement could promote fisheries sustainability in the Mediterranean. Colloca et al. (2013) made similar recommendations, including mesh size increases. A reduction in fishing effort and fishing capacity in northwestern Mediterranean waters (GSAs 7 to 9) for juvenile hake is required, and a stock rebuilding plan seems a logical option. The question is, what type of fishery to rebuild? A considerable reduction in capacity and fishing effort for fine-mesh trawlers was called for by Vasilakopoulos et al. (2014), including the opinion (contrary to that expressed here) that a wholesale switch to a fishery on adult fish be made, with the elimination of a directed fishery on juveniles. Thus, a clash of objectives has been identified that needs resolving. Initially there is a common element between two points of view, namely agreement that a reduction in effort 
on juveniles is called for. However, a fishery aimed at harvesting adult hake, as recommended by Colloca et al. (2013), is not suggested here; it would require mesh size increases, closure of the juvenile fishery, and fishing in offshore areas for stocks of mature hake. Given recent declines in demersal harvests, it is crucial to reduce fishing effort significantly, but this paper supports the idea that an increase in mesh size could be problematical if the calculations are performed with the reciprocal model, and would likely be ineffective if the indirect mortalities to escaping juveniles, and to discards on deck, are substantially higher than with the smaller mesh size. In this author's opinion, further studies on survival rates, locations and ideal habitats of juveniles should be a priority, but protection of juveniles is better achieved by a control of capacity and by nursery closures, rather than by mesh size increases which increase the vulnerability of spawners (Caddy 2007, 2014a). In both cases, an objective confirmation of the species and ecosystem impacts of changing mesh size is called for. Minimizing habitat damage inflicted by trawling in the Mediterranean by closing nursery areas (ages $0+$ and 1) and establishing offshore refugia to exclude towed gear may also be desirable. The history of the fishery supports the idea that, as long as fishing effort remains at the levels in the 1970s-1980s and offshore refugia are protected, fisheries for juveniles of high fecundity species may be sustainable - and as recent events have demonstrated globally, for "adult" fisheries this is a rare phenomenon!

Bioeconomic analyses (e.g. Caddy and Seijo 2002) reflected that a local demand exists for small fish at good market prices. Attempting to replace this harvesting focus on juveniles with a fishery for adult fish will not only be difficult but probably will not satisfy local demand. Unlike many fisheries for sexually mature fish where recruitment overfishing is always a risk, a sustainable inshore fishery for juveniles with minimal regulations on gear type could continue, as long as there is a firm limitation on fleet capacity, and on peak juvenile fishing mortalities, and protection is offered to spawning aggregations.

Druon et al. (2012) noted that European hake habitat occupies specific areas of the Mediterranean, and despite high year-to-year variability, closed areas and seasons are feasible measures to use for protecting "Essential Fish Habitat". In their opinion, fisheries closures should be centred on the nursery grounds, and be large enough to include year-to-year variability of key habitats. In order to avoid the export of fishing effort to offshore grounds, Druon et al. (2012) suggested a seasonal open fishery, possibly with a quota of fishing days as a suitable recovery measure. The question remains how a decline in fishing pressure on the adult components of the stock and their habitat in deeper water can be achieved? Restricting the fishing locations of trawls and other gears taking adult hake would contribute to the protection of the few fish reaching maturity. An inshore season and inshore closures appear suitable measures, but the restoration of deep water habitats and the conservation of the brood stock would require extensive Marine Protected Areas or the restoration of deep water natural refugia at or below the shelf edge, including regulations restricting offshore gears designed for rough bottom, to help protect what remains of the spawning stock.

\section{CONCLUSIONS}

The following are the general conclusions of this paper:

For calculations on population stability, a high natural fecundity needs to be balanced by the higher natural mortality of juveniles. The reciprocal equation provides a reasonable approximation to this mortality vector, and fits the MSVPA results. This procedure is recommended for assessments of fisheries where juveniles are either taken incidentally, or are the principal catch component.

Despite a high fecundity, very few hake eggs survive to maturity after hatching if a reciprocal model is used. For population stability over time, the generation of $0+$ recruits under exploitation must produce at least the same number of $0+$ recruits in the next generation (Caddy 2014b), as reflecting Charnov's principle for a stable population.

A ratio close to unity in predicted age $0+$ recruits between successive generations was shown to be possible at a peak level of exploitation of age $2+$ juveniles, which corresponds roughly to $F(2) \approx 1.2-1.3$. This is below the current estimate of fishing mortality by STECF (2014) at 1.48, and suggests that the intergenerational ratio already corresponds to a declining stock.

A peak $F(2)$ of 1.2-1.3 is too high for stock recovery if we consider a new Charnov limit reference point based on the requirement for reproductive replacement. Applying this approach as a practical form of assessment requires data on age-specific fecundity, and a more intensive study of larval survival in the plankton.

If the high natural mortality rates of juvenile fishes were used in a trophic model, this would probably result in different conclusions than if predation rates are modelled using the natural mortality rates of adults.

It would be highly desirable to identify more directly, the probability of survival to maturity, the abundance and distribution pattern of adult hake, and to calibrate more directly survival of adult females. This would help point to areas where adult refugia should be located.

\section{ACKNOWLEDGEMENTS}

I want to thank Dr. Jordi Lleonart and Dr. Josep Lloret for their help and support acting as editors of the manuscript, and Jordi Corbera who made a significant contribution by improving the figures.

\section{REFERENCES}

Abella A., Auteri R., Serena F. 1995. Some aspects of growth and recruitment of hake in the Northern Tyrrhenian Sea. Cah. Options Méditer. 10: 27-28.

Abella A.J., Caddy J.F., Serena F. 1997. Do natural mortality and availability decline with age? An alternative yield paradigm for juvenile fisheries, illustrated by the hake Merluccius merluc- 
cius fishery in the Mediterranean. Aquat. Living Resour. 10: 257-269.

http://dx.doi.org/10.1051/alr:1997029

Abella A.J, Serena F., Ria M. 2005. Distributional response to variations in abundance over spatial and temporal scales for juveniles of European hake (Merluccius merluccius) in the Western Mediterranean Sea. Fish. Res. 71: 295-310. http://dx.doi.org/10.1016/j.fishres.2004.08.036

Aldebert Y., Recasens L. 1996. Comparison of methods for stock assessment of European hake, Merluccius merluccius in the Gulf of Lions (Northwestern Mediterranean). Aquat. Liv. Res. 9: $13-22$.

http://dx.doi.org/10.1051/alr:1996003

Anthony V.C., Caddy J.F. (eds). 1980. Proceedings of the CanadaU.S. workshop on status of assessment science for N.W. Atlantic lobster (Homarus americanus) stocks (St. Andrews, N.B., 24-26 October 1978). Can. Tech. Rep. Fish. Aquat. Sci. No. 932. Biological Station, St. Andrews, New Brunswick. 186 pp.

Arnason T, Björnsson B., Steinarsson A. 2009. Allometric growth and condition factor of Atlantic cod (Gadus morhua) fed to satiation: effects of temperature and body weight. J. Appl. Ichthyol. 25(4): 401-406. http://dx.doi.org/10.1111/j.1439-0426.2009.01259.x

Bellman M.A., Heppell S.A., Goldfinger C. 2005. Evaluation of a US west coast groundfish habitat conservation regulation via analysis of spatial and temporal patterns of trawl fishing effort. Can. J. Fish. Aquat. Sci. 62: 2886-2900. http://dx.doi.org/10.1139/f05-180

Beverton R.J.H. 1992. Voigtlander, C.W, ed. Session 4: The state of fisheries science. The State of the World's Fisheries Resources: Proceedings of the World Fisheries Congress, Plenary Sessions. Athens.

Beverton R.J.H., Holt S.J. 1957. On the Dynamics of Exploited Fish Populations. Her Majesty's Stationery Office, London. 553 pp.

Bozzano A., Recasens L., Sartor P. 1997. Diet of the European hake Merluccius merluccius (Pisces: Merluccidae) in the Western Mediterranean (Gulf of Lions). Sci. Mar. 61(1): 1-8.

Caddy J.F. 1991. Death rates and time intervals: is there an alternative to the constant natural mortality axiom? Rev. Fish Biol. Fish. 1: 109-138. http://dx.doi.org/10.1007/BF00157581

Caddy J.F. 1993. Towards a comparative evaluation of human impacts on fishery ecosystems of enclosed and semi-enclosed seas. Rev. Fish. Sci. 1(1): 7-95. http://dx.doi.org/10.1080/10641269309388535

Caddy J.F. 2000. Marine catchment basin effects versus impacts of fisheries on semi-enclosed seas. ICES J. Mar. Sci. 57: 628-640. http://dx.doi.org/10.1006/jmsc.2000.0739

Caddy J.F. 2007. Marine habitat and Cover. Oceanographic Methodology Series, UNESCO Publishing, $253 \mathrm{pp}$.

Caddy J.F. 2012. The Role of the GFCM in Regional Fisheries Management. Report of the Directorate General for Internal Policies: Policy department B. The European Parliament Committee on Fisheries, $66 \mathrm{pp}$.

Caddy J.F. 2014a. Why do assessments of demersal stocks largely ignore habitat? ICES J. Mar. Sci. 71: 2114-2126. http://dx.doi.org/10.1093/icesjms/fss199

Caddy J.F. 2014b. The advantages offered by Mediterranean shelf habitats for the conservation of demersal resources using the refugium concept. Biol. Mar. Medit. (in press).

Caddy J.F., Abella A.J. 1999. Reconstructing reciprocal M vectors from length cohort analysis (LCA) of commercial size frequencies of hake, and fine mesh trawl surveys over the same grounds. Fish. Res. 41: 169-175 http://dx.doi.org/10.1016/S0165-7836(99)00015-6

Caddy J.F., Mahon R. 1995. Reference points for fisheries management. FAO Fisheries Technical Paper. No. 347. Rome, FAO. 83 pp.

Caddy J.F., Seijo J.-C. 2002. Reproductive contributions foregone with harvesting: a conceptual framework. Fish. Res. 59: 17-30. http://dx.doi.org/10.1016/S0165-7836(02)00011-5

Caddy J.F., Seijo J.-C. 2011. Destructive fishing practices by bottom trawls: a broad review of research and practice. Cienc. Pesq. special issue 19: 1-58.

Caddy J.F., Sharp G.D. 1986. An ecological framework for marine fishery investigations. FAO Fish.Tech. Pap. 283, 152 pp.

Carpentieri P., Colloca F. 2005. Feeding habits of European hake (Merluccius merluccius) in the central Mediterranean Sea. Fish. Bull. 103: 411-416.

Cesarini A. 1994. Biologia reproduttiva di Merluccius merluccius
(Linee 1758) nel Mar Tirreno Settentrionale. PhD thesis, Univ. Pisa.

Charnov E.L. 1993. Life history invariants. Oxford Series in Ecology and Evolution. Oxford Univ. Press, $167 \mathrm{pp}$.

Chopin F.S., Arimoto T. 1995. The condition of fish escaping from gears - a review. Fish. Res. 21: 315-327. http://dx.doi.org/10.1016/0165-7836(94)00301-C

Colloca F., Cardinale M., Maynou F., et al. 2013. Rebuilding Mediterranean fisheries: a new paradigm for ecological sustainability. Fish and Fisheries 14(1): 89-109. http://dx.doi.org/10.1111/j.1467-2979.2011.00453.x

De Leiva Moreno J.I., Agostini V.N., Caddy J.F. et al. 2000. Is the pelagic-demersal ratio from fisheries landings a useful proxy for nutrient availability? A preliminary data exploration for the semi-enclosed seas around Europe. ICES J. Mar. Sci. 57: 1091-1102. http://dx.doi.org/10.1006/jmsc.2000.0705

Di Natale A., Ratz H.-J., Cheilari A. 2009. Report of the STECF workshop on Mediterranean stock assessment standardization, workshop 09-01 (formerly labeled as SG-ECA/RST/MED 0901), 2-6 March 2009, Murcia, Spain).

Doumenge F. 1966. Hydrologie, biologie et pêche en Mediterranee occidentale. Bull. Soc. Languedocienne Géogr. ( $3^{\circ}$ Serie), 2(4) Oct-Dec: 1-34.

Druon J.N., Spedicato M.T., Peristeraki P., et al. 2012. MPAs or $\mathrm{EFH}$ as a fishery management tool for protecting hake nurseries? Presented at the 2012 Forum of MPAs, Antalya, Turkey.

Farrugio H. 2010. New information concerning fish stocks in the Mediterranean. A seminar held in Brussels, 14 September 2010. (General Fisheries Commission for the Mediterranean). (ec. europa.eu/.../events/140910/henri_farrugio_en.pdf).

Fiorentini L., Caddy J.F., de Leiva J.I. 1997. Long- and short-term trends of Mediterranean fishery resources. GFCM Stud. Rev. 69: 1-72.

Garavelli R., Gross A., Grote B., et al. 2012. Modeling the dispersal of Cape hake ichthyoplankton. J. Plankton Res. 34 (8): 655-669. http://dx.doi.org/10.1093/plankt/fbs039

Hislop J.R.G. 1996. Changes in North Sea gadoid stocks. ICES J. Mar. Sci. 53(6): 1146-1156. http://dx.doi.org/10.1006/jmsc.1996.0140

Hixon M.A., Johnson D.W., Sogard S.M. 2014. BOFFFFs: on the importance of conserving old-growth age structure in fishery populations. ICES J. Mar. Sci. 71(8): 2171-2185. http://dx.doi.org/10.1093/icesjms/fst200

ICES. 2014. WGNSSK Report: (14 Cod - Subarea IV and Divisions IIIa and VIId - Natural mortality by age group. $820 \mathrm{pp}$.

Kolding J., van Zwieten P.A.M. 2011. The tragedy of our legacy: how do global management discourses affect small scale fisheries. Forum for Development Studies 38(3): 267-297. http://dx.doi.org/10.1080/08039410.2011.577798

Larkin P.A. 1978. Fisheries management - an essay for ecologists. Annu. Rev. Ecol. Syst., 9: 57-73.

Link J.S., Demarest C. 2003. Trawl hangs, baby fish, and closed areas: a win-win scenario. ICES J. Mar. Sci. 60: 930-938. http://dx.doi.org/10.1016/S1054-3139(03)00131-0

Lorenzen K. 1996. The relationship between body weight and natural mortality in juvenile and adult fish: a comparison of natural ecosystems and aquaculture. J. Fish Biol. 49: 627-642. http://dx.doi.org/10.1111/j.1095-8649.1996.tb00060.x

Mangel M., MacCall A.D., Brodziak J., et al. 2013. A perspective on steepness, reference points, and stock assessment. Can. J. Fish. Aquat. Sci. 70: 930-940. http://dx.doi.org/10.1139/cjfas-2012-0372

McCoy M.W, Gilloo J.F. 2008. Predicting natural mortality rates of plants and animals. Ecol. Lett. 11(7): 710-716. http://dx.doi.org/10.1111/j.1461-0248.2008.01190.x

Norris J.C. 1991. Further perspectives on Yield per recruit Analysis and Biological reference Points. Can. J. Fish. Aquat. Sci. 48: 2533-2542. http://dx.doi.org/10.1139/f91-294

Orensanz J.M., Jamieson G.S. 1998. The assessment and management of spatially structured stocks: an overview of the North Pacific Symposium on Invertebrate Stock Assessment and Management. In: Jamieson G.S, Campbell A. (eds), Proceedings of the North Pacific Symposium on Invertebrate Stock Assessment and Management. Can. Spec. Publ. Fish Aquat. Sci. 125: 441-459.

Pauly D., Christensen V, Dalsgaard J, et al. 1998. Fishing down marine food webs. Science 279: 860-863 http://dx.doi.org/10.1126/science.279.5352.860 
Payne A.I.L., Rose B., Leslie R.W. 1987. Feeding of hake and a first attempt at determining their trophic role in the South African west coast marine environment. S. Afr. J. Mar. Sci. 5: 471-501. http://dx.doi.org/10.2989/025776187784522667

Petersen C.G.J. 1894. On the biology of our flatfishes and on the decrease of our flatfish fisheries. Rep. Danish Biol. Stn. 4: 1-147.

Powers J.E. 2014. Age-specific natural mortality rates in stock assessment. ICES J. Mar. Sci. 71(7): 1629-1637. http://dx.doi.org/10.1093/icesjms/fst226

Puig R., Canals M., Company J.B., et al. 2012. Ploughing the deep sea floor. Nature 489: 286-289. http://dx. doi.org/10.1038/nature11410

Quaas M.F. Requate T., Ruckes K., et al. 2013. Incentives for Optimal Management of Age-Structured Fish Populations, Res. Energy Econ. 35(2): 113-134. http://dx.doi.org/10.1016/j.reseneeco.2012.12.004

Ragonese S. 2009. Avoidance within a changing assessment paradigm for Mediterranean hake stocks. Medit. Mar. Sci. 10(1): 125-130. http://dx.doi.org/10.12681/mms. 126

Ragonese S., Abella A., Fiorentino F., et al. 2006. Methods for estimating the instantaneous rate of natural mortality $(\mathrm{M})$ in fisheries science, with particular reference to the Mediterranean. Biol. Mer. Medit. 13(3): 1-151.

Ricker W.E. 1958. Handbook of computations for biological statistics of fish populations. JFRB Bulletin, Ottawa, $500 \mathrm{pp}$.

Sangster G.I., Lehmann K. 1993. Assessment of the survival of fish escaping from commercial fishing gears. ICES CM 1993/ B:2 Fish Capture Committee.
Sparholt H. 1990. Improved estimates of the natural mortality rates of nine commercially important species included in the North Sea multispecies VPA model. J. Cons. Perm. Int. Explor. Mer 46: 211-223.

httn://dx.doi.org/10.1093/icesims/46.2.211

STECF. 2014. (Scientific, Technical and Economic Committee for Fisheries of the EU). Assessment of Mediterranean Sea stocks, part1 (STECF-14-17).

Suuronen P. 2005. Mortality of fish escaping trawl gears. FAO Fish. Tech. Pap. 478: 72 pp.

Thompson W.F., Bell F.H. 1934. Biological statistics of the Pacific halibut fishery. (2) Effects of changes in intensity upon total yield and yield per unit of gear. Int. Fish. Comm. Rep. 8

Vasilakopoulos P., Maravillas C.D., Tserpes G. 2014. The alarming decline of Mediterranean fish stocks. Current Biol. 24: $1643-1648$

http://dx.doi.org/10.1016/j.cub.2014.05.070

See also:

Editorial introduction by J. Lloret and J. Lleonart. http://dx.doi.org/10.3989/scimar.04308.14C

Commentary by H.-J. Rätz http://dx.doi.org/10.3989/scimar.04269.09A

Answer by J.F. Caddy http://dx.doi.org/10.3989/scimar.04270.09B 